\title{
DISCRIMINACIÓN SALARIAL POR GÉNERO: ANÁLISIS DE LAS EMPRESAS DEL SECTOR PRIVADO EN EL EJE CENTRAL DE BOLIVIA
}

\section{Mónica Yaneth Cadena Vaca}

\section{RESUMEN}

En el trabajo de investigación se analiza la existencia de discriminación salarial por género en los departamentos del eje central de Bolivia y en las pequeñas, medianas y grandes empresas del área urbana; el estudio se sustenta en la teoría del capital humano de Becker [1], aplicándose la metodología de Oaxaca -Blinder [2], para la descomposición salarial de hombres y mujeres. Se comprueba que en el eje central del país existe discriminación salarial por género, donde la mujer percibe $17 \%$ menos de salario que los hombres pese a contar con las mismas características. En el análisis por departamento, en La Paz se estimó 20.2\% menos de salario, seguido de Santa Cruz con $15.3 \%$ y Cochabamba $14.7 \%$ respectivamente. Se demostró con un $19 \%$ que en las pequeñas empresas existe un mayor grado de discriminación salarial ,13\% en las medianas empresas y $11 \%$ en las grandes empresas, tomando en cuenta la media de los individuos tanto para hombres como para mujeres.

Palabras Clave: Discriminación Salarial, Género, Teoría del Capital Humano, Metodología Oaxaca-Blinder.

DOI: 10.23881/idupbo.020.2-2e 